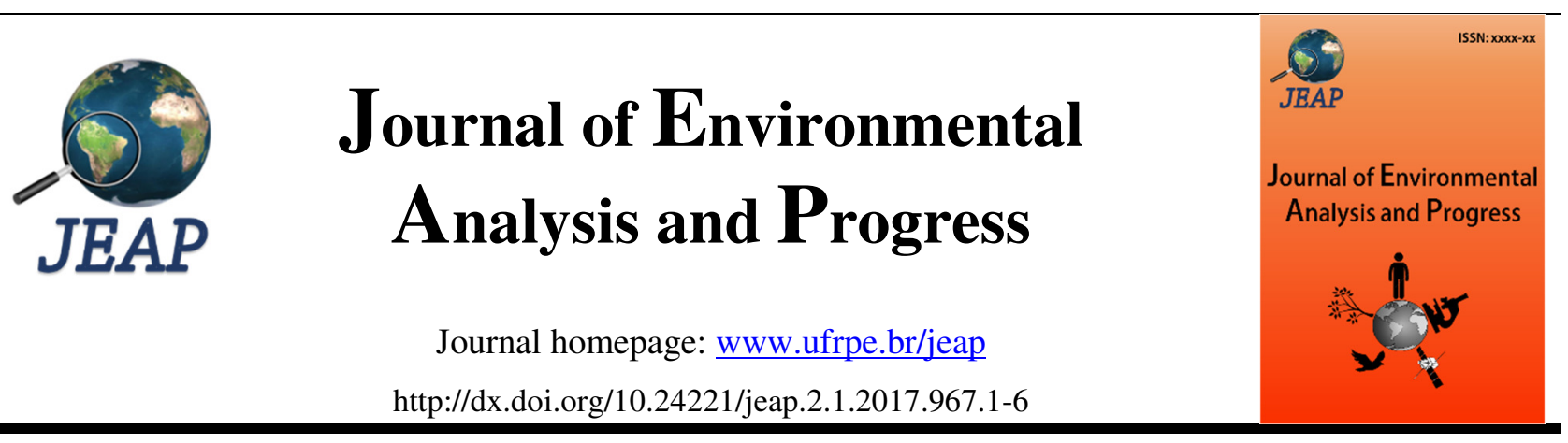

\title{
Plant organ abscission and the green island effect caused by a coleopteran's gall on Miconia cinnamomifolia (Melastomataceae): larval survival and mortality factors
}

\author{
Jean Carlos Santos ${ }^{\mathrm{a}}$, Rodrigo de Queiroga Miranda ${ }^{\mathrm{b}}$, Jarcilene Silva de Almeida-Cortez ${ }^{\mathrm{c}}$ \\ ${ }^{a}$ Universidade Federal de Uberlândia, Instituto de Biologia, Laboratório de Ecologia, Evolução e Biodiversidade, Av. \\ Pará, n. 1720, Uberlândia, Minas Gerais, Brasil. CEP: 38405-320. E-mail: jcsantos@ @ufu.br.

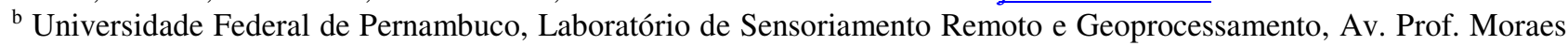 \\ Rego, 1235, Cidade Universitária, Recife, Pernambuco, Brasil. CEP: 50670-901. \\ ${ }^{\mathrm{c}}$ Universidade Federal de Pernambuco, Departamento de Botânica, Centro de Biociências, Av. Prof. Moraes Rego, 1235, \\ Cidade Universitária, Recife, Pernambuco, Brasil. CEP: 50670-901.
}

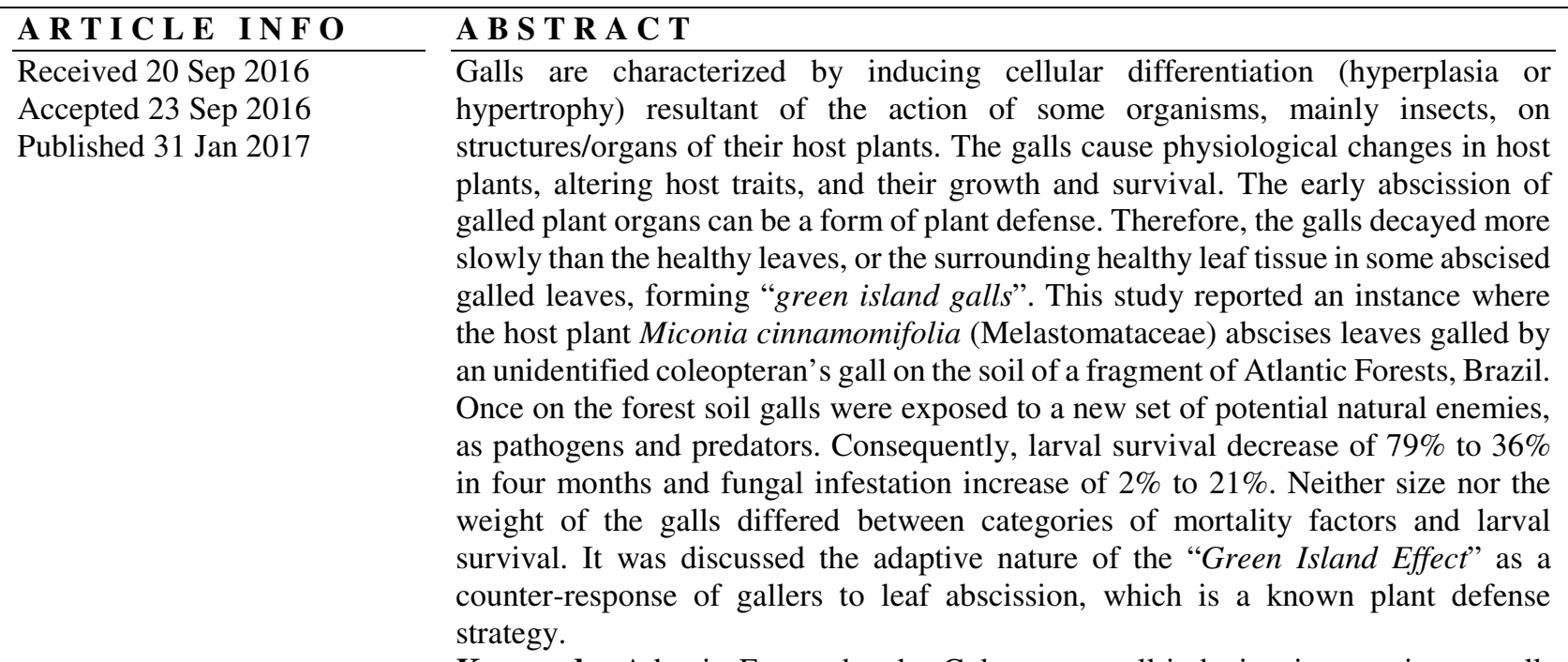

Keywords: Atlantic Forest, beetle, Coleoptera, gall-inducing insects, insect gall, insect-plant interactions, natural enemies.

\section{Introduction}

Galls are produced by induced cellular hypertrophy and/or hyperplasia on plant meristematic tissues, and result in the formation of symmetrical structures on one or more organs (see Raman et al., 2005; Fernandes \& Santos, 2014). Because a galling inducer's development depends strictly on gall's tissues, the effects of galls on their host plants might continue while the gall's metabolism is active (Fay et al., 1996). Galling inducers manipulate their host plant's physiology by channeling nutrients into the gall tissues (e.g. Price et al., 1987; Hartley \& Lawton, 1992; Florentine et al., 2005). Therefore, galled leaves, even when they are matured, may behave as a sink organ rather than a source of nutrients for the plant. That redirection of resources can be so strong that may lead galls to work against not only healthy organs but also even all others galled organs on the same plant (Sacchi et al., 1988; Larson \& Whitham, 1997). In many cases, the negative effect of galls on their host plant is so intense that these herbivores are used as biological control agents of invasive plant species (e.g. Dennill, 1985; Harris \& Shorthouse, 1996; Raman \& Dhileepan, 1999, Badenes-Perez \& Johnson, 2007).

Having nutrients lost heavily by galls, and not invested in development and growth, made plants to evolve through time some mechanisms to protect themselves against gall induction 
(Fernandes, 1988; Fernandes, 1990; Fernandes \& Negreiros, 2001). One of these mechanisms consists of prematurely abscising galled leaves to protect the host plant against a high-intensity herbivory (Craig et al., 1986). This strategy have been recorded as a plant defense against herbivory in several plant systems all over the world (e.g., Stiling et al., 1991; Preszler \& Price, 1993; Fernandes et al., 1999; Yamazaki \& Sugiura, 2008; Fernandes et al., 2012), and can reduce the insect herbivore population as well as the herbivory rate, preventing even future attacks by making the plants less attractive to galling organisms. Although some species of galling insects can maintain tight control over the flow of nutrients into the gall, allowing them to keep their development from larvae till the emergence of adults even on abscised leaves. This phenomenon is called the Green Island Effect (GIE) (Fernandes et al., 2008), and is very similar to what occurs to pathogens (see Walters et al., 2008). The name of it is GIE because of the attacked regions on leaves that always remain apparently active and healthy, and thus green, while the remainder of the leaf senesces and decays (Fernandes et al., 2008).

Overall, it appears there is not enough information on plant organ abscission resulting from galls in the Neotropics. Several abscised galled leaves of Miconia cinnamomifolia (DC.) Naudin (Melastomataceae) were found in the forest soil in a fragment of Atlantic Forest (Brazil). These abscised galled leaves found at that time were totally green, but after a couple of months, they start the deterioration. This study investigated the effect of leaf abscission and GIE on an unidentified coleopteran's gall of $M$. cinnamomifolia (Melastomataceae) and aimed to answer the following goals: (1) to describe the green island effect for the coleopteran gall; (2) to analyze the larval survival and mortality factors of coleopteran's gall at leaf deterioration, and (3) to analyze whether abscised galled leaves differ in size and weight when compared to mortality rates. The first hypothesis predicts that in the abscised galled leaves, their gall-inducers would suffer lower mortality in fist time on the forest soil compared to later galled leaves, where their gallinducers would suffer the higher pressure of natural enemy because of leaf deterioration. On the forest soil, the galls are exposed to a new set of potential natural enemies and an increase in mortality rate over time (Fernandes et al., 2008). The second hypothesis predicts that larger and heavier galls have lower rates of mortality caused by natural enemies.

\section{Material and Methods}

This study was carried out on a fragment of Atlantic Forest in the state of Pernambuco, Brazil; specifically in the Reserva Ecológica de Carnijó Reserva Particular do Patrimônio Natural (RPPN) de Carnijó (Moreno), which is a private reserve located in the Moreno municipality, and has a total area of 126.5 ha. The host plant, Miconia cinnamomifolia (DC.) Naudin is a perennial tree in Atlantic Forest of Northeastern Brazil (Carvalho, 1994; Lorenzi, 1998). It was randomly collected 263 abscised galls from the soil right beneath the canopy of 10 individuals of this specie, and it was repeated at two different times, in March and June 2008 , on single days, and when most galls were mature. In the first sampling, 171 galls at the similar mature developmental stage were sampled. All galls were still presenting their natural coloration (green color), and the leaves that they were attached (Figure 1A). In the second sampling (92 galls), the leaves with galls found on the forest soil were no more green, but mostly black (Figure 1B).

All the sampled galled leaves were placed into plastic bags, numbered, and taken to the laboratory for investigation. Data on gall's biometry, larval survival, and mortality factors were obtained. The length and weight of all galls with a diameter $=0.01 \mathrm{~mm}$ were measured. The mortality factors acting upon the galling larvae were grouped into five categories: (a) predation: when the gall walls were opened by herbivores (i.e., signs of chewing marks); (b) parasitoid attack: when parasitoids were found in the larval chamber; (c) pathogen infestation: when fungus hyphae were found on dead larva inside the gall chamber; (d) unknown death: when the cause of death could not be identified; and (e) survival: when was found a healthy larvae, pupae or emergence hole on the gall (see Fernandes et al., 2008 for details). The galls were carefully dissected using a utility knife (see Fernandes \& Price, 1992).

The larval survival and mortality rates change over time, and the temporal data were tested through a non-parametric Chi-square test. ANOVA was applied to verify differences in size and weight among different mortality rates in the abscised galled leaves. All statistical procedures were performed using Statistica 10.0 (StatSoft, 2011). 

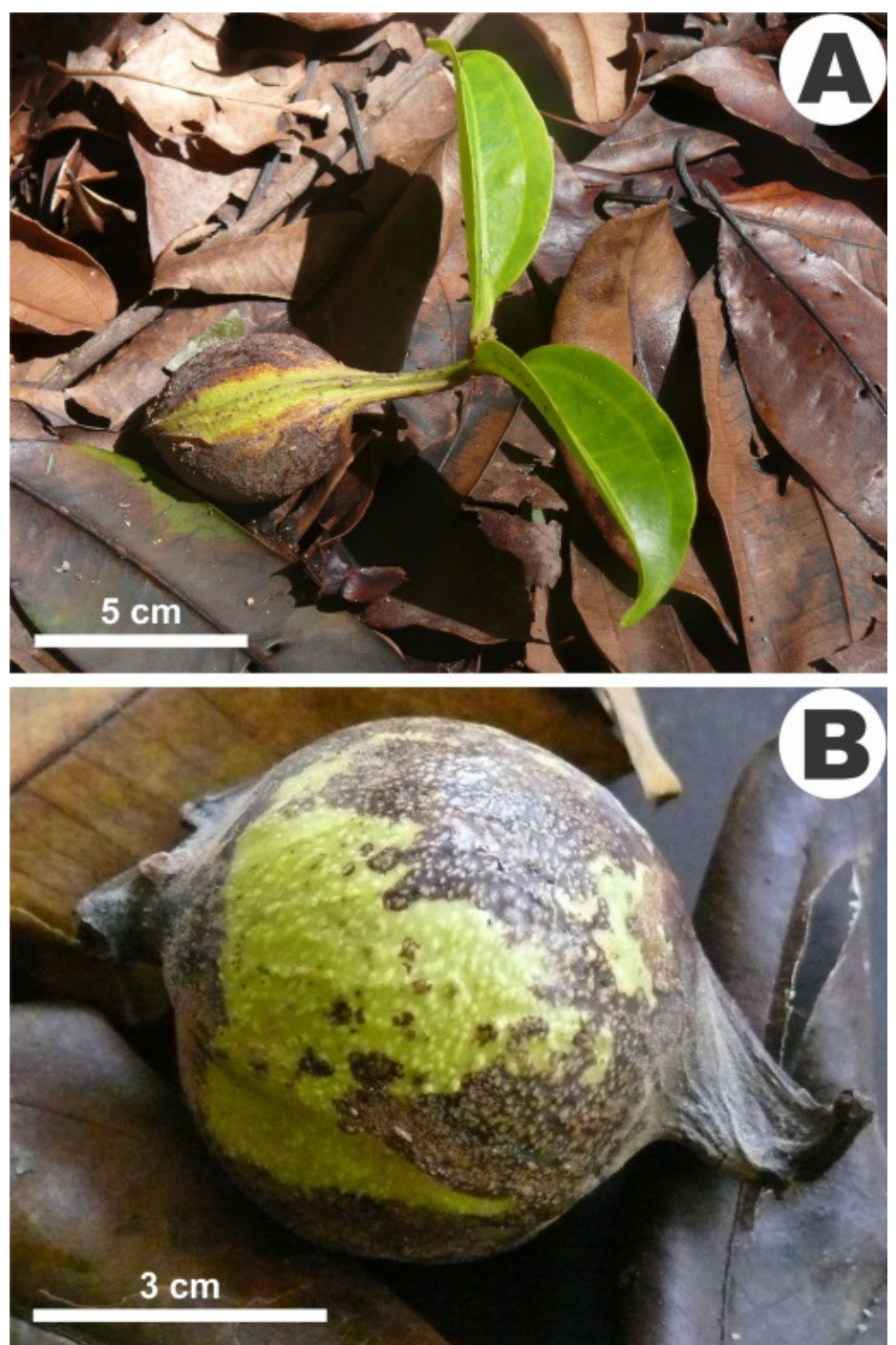

Figure 1. Plant organ abscission and the green island effect caused by an unidentified coleopteran's gall in Miconia cinnamomifolia (DC.) Naudin in Atlantic Forest of Northeastern Brazil. A. Abscised-galled leaf in the forest soil; and B. Gall showing signs of oxidation.

\section{Results}

It was observed that coleopterans induce the galls, have globoid form, color from green to brown, and a single chamber, find on the petiole of the leaves. It was determined $18.52 \mathrm{~g}( \pm 6.06 ; \mathrm{n}=$ $263)$ with $3.04 \mathrm{~cm}( \pm 0.45 \mathrm{~cm} ; \mathrm{n}=263)$ of diameter. Also had inside a blank larva with $0.028 \mathrm{~g}( \pm 0.012$; $\mathrm{n}=135)$ and $0.91 \mathrm{~cm}( \pm 0.19 \mathrm{~cm} ; \mathrm{n}=135)$ of length. It was observed through the study period (79\% to 36\%) a decrease in the survivorship rate, coinciding with an increase in the mortality rate (Figure 2, $\chi^{2}=330.19, \mathrm{df}=4, p<0.0001$ ). Among the top-down mortality factors, pathogen (fungal infestation) was the most important, acting upon coleopteran's larvae, because many pathogenic fungus hyphae were found inside the galls. This top-down mechanism killed more than $2 \%$ of the larvae from the first sampling and more than $21 \%$ of the larvae from the second one. Predation and parasitism rates were inexpressive (Figure 2, $\chi^{2}=$ 330.19 , df $=4, p<0.0001)$. Mortality due to unknown factors represented nearly $18 \%$ of the galls killed in the first sampling and $42 \%$ in the second (Figure 2, $\chi^{2}=330.19, \mathrm{df}=4, p<0.0001$ ). Neither size nor weight of the galls differed between the categories of mortality factors and larval survival [first sampling, gall weight $(\mathrm{g}) p=$ 0.25 and gall length $(\mathrm{mm}) p=0.70(\mathrm{n}=171$ galls $)$, second sampling, gall weight $(\mathrm{g}) p=0.14$ and gall length $(\mathrm{mm}) p=0.08(\mathrm{n}=92$ galls $)]$. 


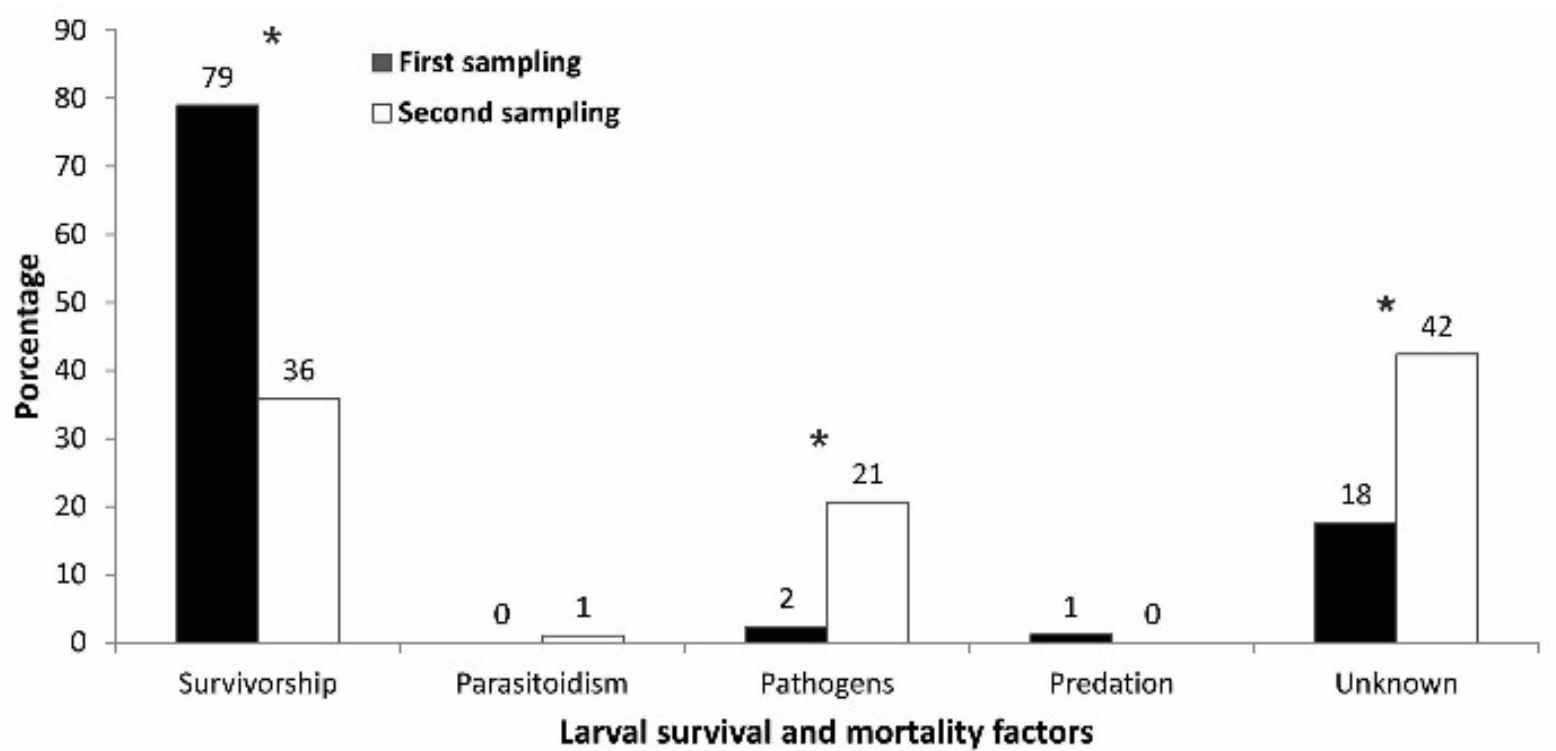

Figure 2. Proportion survival and mortality rates caused by predators, parasites, pathogens, and unknown factors on galls induced by an unidentified species of coleopteran's gall in Miconia cinnamomifolia (DC.) Naudin in the Atlantic Forest soil, Northeastern Brazil. First sampling: galls showed a similar mature developmental stage with natural coloration (green) and second sampling: galls major in black, showing signs of oxidation.

\section{Discussion}

It was observed that the defense effect of the host plant on the gall-inducing insect was attenuated by some counter-adaptations of the coleopteran's larvae, and that reduced the impact of this herbivore on the host plant. The coleopteran's gall of Miconia cinnamomifolia (Melastomataceae) from first sampling showed a high survival rate (79\%), but in the second sampling, four months later, the rate dropped to $36 \%$. This success may be related to one new and efficient mechanism of galls survival, known as GIE. GIE was described recently by Fernandes et al. (2008) in Neea madeirana (Nyctaginaceae), where the plant abscised frequently more leaves galled by two species of Bruggmannia (Diptera: Cecidomyiidae) than ungalled leaves in a rain forest in Amazonia, Brazil. Once fallen on the forest soil, the authors observed that the ungalled leaves decayed quickly, while the galled leaves kept showing signs of localized maintenance of healthy tissues (the green island effect).

The coleopteran's galls found showed a significant dramatic increase, more than 10-folds, in its mortality's inducer due to fungal infestation after four months on the forest soil was compared to the first sampling. The results indicate that the more time the galls became exposed to the ground, the more was the probability of a gall being infested by pathogens or killed by natural enemies. The fungal attack is not a newly known cause of galls mortality. Fernandes et al. (2008) also found that, on two Bruggmannia species. They observed a higher proportion of galled leaves on the ground than in the canopy of N. madeirana. Consequently, their galling species showed a minimum of a fivefold increase in mortality due to pathogens (fungi and bacteria) compared to the galls that were still retained on the host tree.

The gall size has been related to the performance of gall-inducing insects in several studies (e.g., Sopow \& Quiring, 2001; Egan et al., 2012), and with its mortality rates by natural enemies (Figueiredo et al., 2014). In this study, neither size nor the weight of the coleopteran's galls differed between the categories of mortality factors and larval survival (performance), suggesting that the gall-size not give additional protection to the gallers against the natural enemies.

\section{Conclusion}

In summary, this study discussed the adaptive nature of the "Green Island Effect" as a counter-response of gallers to leaf abscission, known as plant defense. However, detailed studies are needed on the gall's physiology (e.g., photosynthesis, phenolic compound, nutrients, among others) and the relationship with the galls inducing organisms to understand the mechanisms involved in this relationship. There is scarce information on "Green Island Effect", especially on insects. Once on the forest floor, galls are exposed to many potential natural enemies but galled leaves of $M$. cinnamomifolia can maintain healthy tissues for months. It is probably a gall 
inducer adaptive trait against organ abscission of its host plant.

\section{Acknowledgements}

The authors thank the Estação Ecológica de Carnijó for the logistical support, and the grants provided by the Fundação de Amparo à Ciência e Tecnologia de Pernambuco-FACEPE/Conselho Nacional de Desenvolvimento Científico e Tecnológico-CNPq (DCR-0087-2.05/06). Jean Carlos Santos thanks to Conselho Nacional de Desenvolvimento Científico e Tecnológico (CNPq) and Coordenação de Aperfeiçoamento de Pessoal de Nível Superior (CAPES).

\section{References}

BADENES-PEREZ, F. R.; JOHNSON, M. T. 2007. Ecology and impact of Allorhogas sp. (Hymenoptera: Braconidae) and Apion sp. (Coleoptera: Curculionoidea) on fruits of Miconia calvescens DC (Melastomataceae) in Brazil. Biological Control, v.43, p.317-322.

CARVALHO, P. E. R. 1996. Espécies florestais brasileiras: recomendações silviculturais, potencialidades e uso da madeira. Embrapa/CNPF, Colombo.

CRAIG, T. P.; PRICE, P. W.; ITAMI, J. K. 1986. Resource regulation by a stem-galling sawfly on the arroyo willow. Ecology, v.67, p.419-425.

DENNILL, G. B. 1985. The effect of the gall wasp Trichilogaster acaciaelongifoliae (Hymenoptera: Pteromalidae) on reproductive potential and vegetative growth of the weed Acacia longifolia. Agr. Ecosyst. Environ., v.14, p.53-61.

EGAN, S. P.; HOOD, G. R.; OTT, J. R. 2012. Natural selection on gall size: variable contributions of individual host plants to population-wide patterns. Evolution, v.65, p.35433557.

FAY, P. A.; HARTNETT, D. C.; KNAPP, A. K. 1996. Plant tolerance of gall-insect attack and gallinsect performance. Ecology, v.77, p.521-534.

FERNANDES, G. W. 1990. Hypersensitivity: a neglected plant resistance mechanism against insect herbivores. Environ. Entomol., v.19, p.11731182 .

FERNANDES, G. W. 1998. Hypersensitivity as a phenotypic basis of plant induced resistance against a galling insect (Diptera: Cecidomyiidae). Environ. Entomol., v.27, p.260-267.
FERNANDES, G. W.; CASTRO, F. M. C.; MARQUES, E. S. A. 1999. Leaflet abscission caused by a gall induced by Melaphis rhois (Aphididae) on Rhus glabra (Anarcadiaceae). Int. J. Ecol. Environ. Sci., v.25, p.63-69.

FERNANDES, G. W.; DE MARCO, J. P.; SCHÖNROGGE, K. 2008. Plant organ abscission and the green island effect caused by gall midges (Cecidomyiidae) on tropical trees. Arthropod-Plant Interact., v.2, p.93-99.

FERNANDES, G. W.; NEGREIROS, D. 2001. The occurrence and effectiveness of hypersensitive reaction against galling herbivores across host taxa. Ecol. Entomol., v.26, p.46-55.

FERNANDES, G. W.; PRICE, P. W. 1992. The adaptive significance of insect gall distribution: survivorship of species in xeric and mesic habitats. Oecologia, v.90, p.14-20.

FERNANDES, G. W.; SANTOS, J. C. Neotropical Insect Galls. Springer, Dordrecht.

FERNANDES, G. W.; SANTOS, J. C.; GOMES, V. M. 2012. Misleading herbivory in a tropical tree. Arthropod-Plant Interact., v.1, p.1-6.

FIGUEIREDO, J. M. A.; SANTOS, J. C.; FERNANDES, G.W.; MARTINS, R. P. 2014. Natural selection on a tropical system: gall-size distribution on Waltheria indica (Malvaceae). In: FERNANDES, G. W.; SANTOS, J. C. (eds) Neotropical Insect Galls, pp.115-128. Springer, Dordrecht.

FLORENTINE, S. K.; RAMAN, A.; DHILEEPAN, K. 2005. Effects of gall induction by Epiblema strenuana on gas exchange, nutrients, and energetics in Parthenium hysterophorus. BioControl, v.50, p.787-801.

HARRIS, P.; SHORTHOUSE, J. D. 1996. Effectiveness of gall inducers in weed biological control. Can. Entomol., v.128, p.1021-1055.

HARTLEY, S. E.; LAWTON, J. H. 1992. Host plant manipulation by gall insects: a test of the nutrition hypothesis. J. Anim. Ecology, v.61, p.113-119.

LARSON, K. C.; WHITHAM, T. G. 1991. Manipulation of food resources by a gall-forming aphid: the physiology of sink-source interactions. Oecologia, v.88, p.15-21.

LORENZI, H. 1998. Árvores brasileiras: manual 
de identificação e cultivo de plantas arbóreas nativas do Brasil. Plantarum.

PRESZLER, R. W.; PRICE, P. W. 1993. The influence of Salix leaf abscission on leaf-miner survival and life history. Ecol. Entomol., v.18, p.150-154.

PRICE, P. W.; FERNANDES, G. W.; WARING, G. L. 1987. Adaptive nature of insect galls. Environ. Entomol., v.16, p.15-24.

RAMAN, A.; DHILEEPAN, K. 1999. Qualitative evaluation of damage by Epiblema strenuana (Lepidoptera: Tortricidae) to the weed Parthenium hysterophorus (Asteraceae). Ann. Entomol. Soc. Am., v.92, p.717-723.

RAMAN, A.; SCHAEFER, C. W.; WRITERS, T. M. 2005. Biology, ecology and evolution of gallinducing arthropods. Science Publishers Inc, Enfield.

SACCHI, C. F.; PRICE, P. W.; CRAIG, T. P.; ITAMI, J. K. 1988. Impact of the shoot galler attack on sexual reproduction in the arroyo willow. Ecology, v.69, p.2021-2030.

SOPOW, S. L.; QUIRING, D. T. 2001. Is gall size a good indicator of adelgid fitness? Entomol. Exp. Appl., v.99, p.267-271.

STATSOFT INC. 2011. Statistica (data analysis software system), version 10 .

STILING, P.; SIMBERLOFF, D.; BRODBECK, B. V. 1991. Variation in rates of leaf abscission between plants may affect the distribution patterns of sessile insects. Oecologia, v.88, p.367-370.

WALTERS, D. R.; MCROBERTS, N.; FITT, B. D. L. 2008. Are green islands red herrings? Significance of green islands in plant interactions with pathogens and pests. Biol. Rev., v.83, p.79102.

YAMAZAKI, K.; SUGIURA, S. 2008. Deer predation on leaf miners via leaf abscission. Naturwissenschaften, v.95, p.263-268. 